\title{
In vitro investigations of the potential health benefits of Australian-grown faba beans (Vicia faba L.): chemopreventative capacity and inhibitory effects on the angiotensin-converting enzyme, $\alpha$-glucosidase and lipase
}

\author{
Siem D. Siah ${ }^{1,2,3}$, Izabela Konczak ${ }^{1 *}$, Samson Agboola ${ }^{2,4}$, Jennifer A. Wood ${ }^{5}$ and \\ Christopher L. Blanchard ${ }^{2,3}$ \\ ${ }^{1}$ Food Futures Flagship, CSIRO Food and Nutritional Sciences, 11 Julius Avenue, North Ryde, NSW 2113, Australia \\ ${ }^{2}$ EH Graham Centre for Agricultural Innovation, Wagga Wagga Agricultural Institute, Pine Gully Road, \\ Wagga Wagga, NSW 2650, Australia \\ ${ }^{3}$ School of Biomedical Sciences, Charles Sturt University, Wagga Wagga, NSW 2678, Australia \\ ${ }^{4}$ School of Agricultural and Wine Sciences, Charles Sturt University, Wagga Wagga, NSW 2678, Australia \\ ${ }^{5}$ NSW Department of Primary Industries, Tamworth Agricultural Institute, Calala, NSW 2340, Australia \\ (Submitted 6 September 2011 - Accepted 26 October 2011)
}

\section{Abstract}

The functional properties, including antioxidant and chemopreventative capacities as well as the inhibitory effects on angiotensin-converting enzyme (ACE), $\alpha$-glucosidase and pancreatic lipase, of three Australian-grown faba bean genotypes (Nura, Rossa and TF(IC*As)*483/13) were investigated using an array of in vitro assays. Chromatograms of on-line post column derivatisation assay coupled with HPLC revealed the existence of active phenolics (hump) in the coloured genotypes, which was lacking in the white-coloured breeding line, $\operatorname{TF}\left(\mathrm{IC}^{*} \mathrm{As}\right)^{*} 483 / 13$. Roasting reduced the phenolic content, and diminished antioxidant activity by $10-40 \%$ as measured by the reagentbased assays (diphenylpicrylhydrazyl, 2,2'-azino-bis(3-ethylbenzthiazoline-6-sulphonic acid) and oxygen radical absorbance capacity) in all genotypes. Cell culture-based antioxidant activity assay (cellular antioxidant activity) showed an increase of activity in the coloured genotypes after roasting. Faba bean extracts demonstrated cellular protection ability against $\mathrm{H}_{2} \mathrm{O}_{2}$-induced DNA damage (assessed using RAW264.7 cells), and inhibited the proliferation of all human cancer cell lines (BL13, AGS, Hep G2 and HT-29) evaluated. However, the effect of faba bean extracts on the non-transformed human cells (CCD-18Co) was negligible. Flow cytometric analyses showed that faba bean extracts successfully induced apoptosis of HL-60 (acute promyelocytic leukaemia) cells. The faba bean extracts also exhibited ACE, $\alpha$-glucosidase and pancreatic lipase inhibitory activities. Overall, extracts from Nura (buff-coloured) and Ross $a$ (red-coloured) were comparable, while $\operatorname{TF}\left(I C^{*} A s\right)^{*} 483 / 13$ (white-coloured) contained the lowest phenolic content and exhibited the least antioxidant and enzyme inhibition activities. These results are important to promote the utilisation of faba beans in human diets for various health benefits.

Key words: Faba beans: Phenolic compounds: Antioxidants: Health benefits

Faba beans (Vicia faba L.), also commonly known as fava, horse and broad beans, are widely consumed in different parts of the world including Egypt, Sudan, The Netherlands, Spain, Saudi Arabia, India and China. Their seed coat colours range from white, buff (or beige), purple, green to red, with the buff-coloured beans being the most commonly accepted for human consumption. In 2008, the worldwide production of dry faba beans was approximately $4 \cdot 1$ million tonnes, and the export trade was valued at approximately US\$291 million ${ }^{(1)}$.
Faba beans are grown in Australia as a break crop and exported to the Middle East and $\mathrm{Asia}^{(2)}$, with export trade valued at approximately US\$58 million in $2008^{(1)}$.

Pulses are well known to be an economical source of protein, carbohydrate and fibre, and are low in fat. Pulses are also incorporated in human diets for their additional nutritional benefits, especially their microconstituents including phenolic compounds, oligosaccharides ${ }^{(3)}$, enzyme inhibitors, phytosterols and saponins ${ }^{(4,5)}$. Intake of legumes is reported to potentially

Abbreviations: ABTS, 2,2'-azino-bis(3-ethylbenzthiazoline-6-sulphonic acid); ACE, angiotensin- converting enzyme; CAA, cellular antioxidant activity; $\mathrm{DPPH}$, diphenylpicrylhydrazyl; $\mathrm{EC}_{50}$, half maximal effective concentration; EMEM, Eagle's minimum essential medium; IC 50 , half maximal inhibitory concentration; IMDM, Iscove's modified Dulbecco's medium; ORAC, oxygen radical absorbance capacity; TEAC, Trolox equivalent antioxidant capacity; TFC, total flavonoid content; TPC, total phenolic content.

*Corresponding author: I. Konczak, fax +6129490 8499, email izabela.konczak@csiro.au 
lower the risk of cancer ${ }^{(6)}, \mathrm{CVD}^{(7)}$, hypertension and diabetes $^{(8)}$. Some of the microconstituents are currently marketed as functional foods and nutraceutical ingredients ${ }^{(9)}$. Also, there have been many attempts to incorporate pulses into food products for enrichment of product quality and additional health benefits $^{(10,11)}$.

A wide range of methods are used to prepare faba beans including soaking, boiling and roasting. Heating was reported to result in significant decreases in polyphenols, enzyme inhibitors, phytic acid, some minerals and vitamins, but increase protein digestibility of faba beans ${ }^{(12,13)}$. Interestingly, Acar et al. ${ }^{(14)}$ reported that roasting at $150^{\circ} \mathrm{C}$ for $60 \mathrm{~min}$ increased the antioxidant capacity of different types of pulses including black bean, borlotti bean, kidney bean, red soybean, yellow bean, giant lentils and chickpea, with an initial fall observed in the yellow and red soybeans after roasting for $10 \mathrm{~min}$. Comparatively, in faba beans, the tannin content increased after roasting at $149^{\circ} \mathrm{C} / 20 \mathrm{~min}$ and $177^{\circ} \mathrm{C} / 18 \mathrm{~min}$, but decreased after roasting at $204^{\circ} \mathrm{C} / 14 \mathrm{~min}$ and $232^{\circ} \mathrm{C} / 12 \min ^{(15)}$.

Phenolic compounds are one of the microconstituents which have been gaining an increasing interest for their healthpromoting properties, largely defined by their antioxidant activity. Previous research has reported different types of phenolic compounds found in faba beans, such as procyanidins ${ }^{(16-18)}$, catechins $^{(19)}$, flavonols ${ }^{(20)}$, isoflavones ${ }^{(21)}$, phenolic acids $^{(22)}$ and tannins ${ }^{(23-25)}$, which are natural antioxidants ${ }^{(26)}$. Phenolic compounds extracted from a variety of plant materials have been reported to have an ability to inhibit carbohydrate and lipid digestion, therefore preventing them from absorption. These could potentially lower the postprandial hyperglycaemic response and contribute towards weight maintenance ${ }^{(27,28)}$.

Phenolic extracts of different types of beans were found to have antioxidant activities ${ }^{(26)}$, protective effects against radical-induced DNA damage ${ }^{(29)}$, as well as antimutagenic ${ }^{(30)}$ and anticancer ${ }^{(31)}$ properties. Many have reported substantial amounts of phenolic compounds in raw ${ }^{(32)}$ and cooked faba beans ${ }^{(33)}$, but limited reports focus on the health benefits of faba bean phenolic compounds and also on the impact of food preparation heat processes on the retention and activities of phenolic compounds. The present study hence aims to investigate in vitro the potential health benefits of crude extracts from raw and cooked faba beans in the prevention of chronic diseases including hypertension, diabetes, obesity and different types of cancers. The results could support increased consumption of faba beans and the development of new food products using faba beans, enhancing the exploitation of the crop and providing better returns to growers.

\section{Materials and methods}

\section{Plant materials}

For the purpose of the study, three faba bean genotypes including cv. Nura (buff-coloured), cv. Rossa (red-coloured) and breeding line $T F\left(I C^{*} A s\right)^{*} 483 / 13$ (white-coloured) were grown at the Wagga Wagga Agricultural Institute experimental field in NSW, Australia in 2008. Harvested beans were air-dried and then stored at $-20^{\circ} \mathrm{C}$ until analysis.

\section{Dry roasting}

Roasting was performed at $150^{\circ} \mathrm{C}$ using dry heat in an oven (Premium Laboratory Oven, Thermoline Scientific) for $1 \mathrm{~h}$ (approximately $50 \mathrm{~g}$ per batch in a single layer on a foil tray and agitated gently after $30 \mathrm{~min}$ for uniform heating). Roasted beans were cooled at room temperature and ground into flour using an IKA-Universalmühle M20 Grinder (Janke and Kunkel).

\section{Preparation of phenolic extracts}

Extraction of phenolic compounds was carried out by dispersing the flour in aqueous acetone (acetone-water, 70:30, v/v) ${ }^{(16)}$ in a solid:solvent ratio of $1: 10$ and shaking for $2 \mathrm{~h}$ at room temperature. The supernatant was collected after centrifugation at $4000 \mathrm{~g}$ using an Eppendorf 5415D Centrifuge (EppendorfNetheler-Hinz) for $5 \mathrm{~min}$ at $5^{\circ} \mathrm{C}$. A second extraction was performed on the residue and the extracts were pooled, concentrated under reduced pressure at $40^{\circ} \mathrm{C}$ using a rotary evaporator (Rotavapor R-205; Buchi) and then freeze-dried using a ChristAlpha 1-4 freeze dryer (Biotech International). The extracts were stored at $-20^{\circ} \mathrm{C}$ until used. Distilled water was used to dissolve the dried extract and the reconstituted extracts were filtered through $0.45 \mu \mathrm{m}$ Millipore filters (Millipore Australia Pty Ltd, Australia) before analysis. All extractions and measurements were performed at least in triplicate, except extractions from the raw beans which were performed in duplicate.

\section{Total phenolic content, total flavonoid content and antioxidant capacity assays}

The total phenolic content (TPC) assay was conducted according to Konczak et $a l^{(34)}$. The total flavonoid content (TFC), diphenylpicrylhydrazyl (DPPH) radical scavenging capacity and Trolox equivalent antioxidant capacity (TEAC) assays were performed as described by Michalska et al. ${ }^{(35)}$. The oxygen radical absorbance capacity (ORAC) assay was carried out as described by Prior et al. ${ }^{(36)}$.

\section{Preparation of 2,2'-azino-bis(3-ethylbenzthiazoline- 6-sulphonic acid) free radical for post column derivatisation assay}

The 2,2'-azino-bis(3-ethylbenzthiazoline-6-sulphonic acid) $(\mathrm{ABTS})^{+}$radical cation was prepared by dissolving ABTS (Sigma Aldrich) in deionised water $(7 \mathrm{~mm})$ and mixed with $2.45 \mathrm{~mm}$ of potassium persulphate overnight to allow complete reaction. The solution was diluted using distilled water to obtain an absorbance of $0.70(\mathrm{SD} 0.02)$ at $734 \mathrm{~nm}$ and filtered through a polypropylene membrane $(0.45 \mu \mathrm{m})^{(37)}$.

\section{On-line post column derivatisation with HPLC}

Analysis of the antioxidant activity was carried out on-line using ABTS cation radical. The HPLC system (ProStar model 410, Varian, Inc., Australia) consisted of a Phenomenex Luna $5 \mathrm{U}$ C18 column (100A pore size; $150 \times 3 \mathrm{~mm}$ ), preceded by a guard column (Phenomenex, $4 \times 3 \mathrm{~mm}$ ), a Varian 240I pump 
and a Varian 335 PDA Detector. The mobile phase A was wateracetic acid (99:1; v/v) and phase $B$ was methanol-acetonitrile $(50: 50 ; \mathrm{v} / \mathrm{v})$. An aliquot $(8 \mu \mathrm{l})$ of the extract sample $(50 \mathrm{mg} / \mathrm{ml})$ dissolved in solvent A was injected and eluted in a gradient of $0-48 \%$ phase $B$ for $40 \mathrm{~min}$ at a flow-rate of $0.4 \mathrm{ml} / \mathrm{min}$. UV spectra were recorded at $280 \mathrm{~nm}$. Post column antioxidant activity on-line was determined on the HPLC eluent from the system which arrived at a 'T' piece and reacted with $\mathrm{ABTS}^{+}$ that was added at a flow rate of $0.4 \mathrm{ml} / \mathrm{min}$. The absorbance of the reaction products was measured by a UV-Vis detector (Model 9050, Varian, Inc., Australia) at $414 \mathrm{~nm}$.

\section{Cell cultures}

All cells lines were purchased from the American Type Culture Collection except the BL13 (human bladder transitional cell carcinoma) cells which were obtained from Dr D. Brookes ${ }^{(38)}$. All cells were cultured at $37^{\circ} \mathrm{C}$ in a humidified $5 \% \mathrm{CO}_{2}-95 \%$ air atmosphere. BL13 cells were cultured in Roswell Park Memorial Institute medium (Invitrogen Corporation); AGS (gastric adenocarcinoma) in F-12K Ham's medium (Invitrogen Corporation); Hep G2 (hepatocellular) in Eagle's minimum essential medium (EMEM; Sigma-Aldrich); HT-29 (colorectal adenocarcinoma) in McCoy's 5 a modified medium (Invitrogen Corporation); RAW264.7 (macrophage; Abelson murine leukaemia virus-induced tumour) in Dulbecco's modified Eagle's medium (Sigma-Aldrich); HL-60 (acute promyelocytic leukaemia) in Iscove's modified Dulbecco's medium (IMDM; Invitrogen Corporation) and CCD-18Co (colon normal) cells were cultured in EMEM. Each medium was supplemented with $100 \mu \mathrm{g} / \mathrm{ml}$ streptomycin and 1000 units/ml penicillin (Invitrogen Corporation) and 10\% fetal calf serum, with the exception of IMDM for HL-60 which required $20 \%$ serum.

\section{Cellular antioxidant activity assay}

The assessment of cellular antioxidant activity (CAA) was determined according to Tan et al. ${ }^{(39)}$ and Wolfe \& Liu ${ }^{(40)}$. Briefly, $1 \times 10^{5} / \mathrm{ml}$ of Hep G2 cells were plated in a ninety-six-well microplate and incubated for $24 \mathrm{~h}$. Next, the medium was removed and the cells were washed using PBS. The cells were then treated with different concentrations of faba bean extracts ( $10 \mu \mathrm{l}$ in PBS), added to $80 \mu \mathrm{l}$ of PBS, followed by the addition of $2^{\prime}, 7^{\prime}$-dichlorfluorescein-diacetate (Sigma-Aldrich) (10 $\left.\mu \mathrm{l}\right)$ ( $250 \mu \mathrm{M}$ in PBS), and incubated for $1 \mathrm{~h}$. Subsequently, the cells were washed using PBS $(100 \mu \mathrm{l})$ and added to $100 \mu \mathrm{l}$ of 2,2'-azobis (2-amidinopropane) dihydrochloride in Hank's balanced salt solution $(600 \mu \mathrm{M})$. The fluorescence was measured at $485 \mathrm{~nm}$ excitation and $538 \mathrm{~nm}$ emission wavelengths for every $5 \mathrm{~min}$ in $1 \mathrm{~h}$. The final fluorescence values were corrected for the blank sample readings, and a time $v$. fluorescence graph was plotted. A quercetin standard was used to express the results as quercetin equivalents per $g$ of dry weight of beans.

\section{Antiproliferation assay}

The assessments of antiproliferation activity of the faba bean

crude extracts were carried out on the adhesive cells, BL13,
AGS, Hep G2 and HT-29 using 3-(4,5-dimethylthiazol-2-yl) -2,5-diphenyltetrazolium bromide colorimetric assay, as outlined by Tan et al. ${ }^{(39)}$. PBS was used to dissolve the sample extracts.

\section{Assessment of apoptosis and cytolysis by flow cytometry}

Suspensions ( $4.5 \mathrm{ml})$ of HL-60 cells $\left(2.5-5 \times 10^{5} / \mathrm{ml}\right)$ were treated with $225 \mu \mathrm{l}(0.8 \mathrm{mg} / \mathrm{ml})$ of extracts for 3,12 and $24 \mathrm{~h}$ in $25 \mathrm{~cm}^{2}$ culture flasks in triplicate. Untreated cells were used as a control. For the dose-response evaluation, the cells were treated with three different extract concentrations (0.4, 0.8 and $1.6 \mathrm{mg} / \mathrm{ml}$ in PBS) for $24 \mathrm{~h}$. Cells were stained with Annexin V-Alexa Fluor 488 annexin V/Dead cell apoptosis kit with Alexa Flour 488 annexin V and PI for flow cytometry (Invitrogen Corporation) according to the manufacturer's directions. After the set incubation time, the cells were harvested, washed with cold PBS and resuspended in Annexin-binding buffer. Following this, $100 \mu \mathrm{l}$ of cells were stained by adding $5 \mu \mathrm{l}$ of Annexin $\mathrm{V}$ and $1 \mu \mathrm{l}$ of propidium iodine and incubated for $10 \mathrm{~min}$ at room temperature. Next, the cells were mixed with $400 \mu \mathrm{l}$ of Annexin-binding buffer and immediately placed on ice. Analysis was performed by flow cytometry using a FACSCalibur flow cytometer (Becton Dickinson) and FlowJo software (TreeStar Inc.) to determine the extent of cell apoptosis and lysis. From 3000 to 10000 events were acquired for each measurement and the cell populations were gated for analysis.

\section{Cellular protection against $\mathrm{H}_{2} \mathrm{O}_{2}$}

The cellular protection against $\mathrm{H}_{2} \mathrm{O}_{2}$ assay was carried out using RAW264.7 cells according to Tan et al. ${ }^{(39)}$, except that the concentration of $\mathrm{H}_{2} \mathrm{O}_{2}$ used was $40 \mathrm{~mm}$.

\section{Angiotensin-converting enzyme inhibition assay}

The angiotensin-converting enzyme (ACE) inhibition assay was carried out as described in Shalaby et al. ${ }^{(41)}$ using furanacroloylPhe-Glu-Glu as substrates. Results were expressed as $\mu \mathrm{g}$ of captopril equivalents/g of dry weight of beans.

\section{$\alpha$-Glucosidase inhibition assay}

The $\alpha$-glucosidase inhibition was determined as described by Ikarashi et al. ${ }^{(27)}$ using sucrose as substrates, with slight modifications. An $\alpha$-glucosidase enzyme solution was prepared by dissolving $100 \mathrm{mg}$ of intestinal acetone powders from rat (Sigma-Aldrich) in $1 \mathrm{ml}$ of $0 \cdot 1 \mathrm{~m}$ maleate buffer ( $\mathrm{pH} 6$ ) and homogenised using an ultrasonicator for 6 min on a $30 \mathrm{~s}$ rest cycle. The enzyme solution was centrifuged at $3000 \boldsymbol{g}$ for $30 \mathrm{~min}$ and the supernatant was diluted to $1: 2(\mathrm{v} / \mathrm{v})$ using the buffer solution. Sample solutions $(20 \mu \mathrm{l})$ were mixed with $2 \%$ sucrose $(\mathrm{w} / \mathrm{v})$ in maleate buffer $(20 \mu \mathrm{l})$. The enzymatic reaction was initiated by adding enzyme solution $(20 \mu \mathrm{l})$ to the mixture and incubated at $37^{\circ} \mathrm{C}$ for $60 \mathrm{~min}$. The enzymatic reaction was terminated by heating at $100^{\circ} \mathrm{C}$ for $10 \mathrm{~min}$. Sample mixture $(20 \mu \mathrm{l})$ was then used to react with the colour reagent (Glucose CII-Test Wako, Wako Pure Chemical Industries) $(3 \mathrm{ml})$ at $37^{\circ} \mathrm{C}$ 
for $5 \mathrm{~min}$ and the absorbance was measured at $505 \mathrm{~nm}$. Negative controls were prepared as described by replacing the sample solution with the buffer solution, whereas control and sample blanks were prepared by replacing the enzyme and sucrose solutions with the buffer solutions. The relative $\alpha$-glucosidase inhibition was calculated using the following formula:

$$
\begin{aligned}
\text { Percentage of inhibition }= & \left\{\left(A_{\mathrm{CB}}-A_{\mathrm{C}}\right)-\left(A_{\mathrm{SB}}-A_{\mathrm{S}}\right)\right\} / \\
& \left(A_{\mathrm{CB}}-A_{\mathrm{C}}\right) \times 100
\end{aligned}
$$

where $A_{\mathrm{S}}$ and $A_{\mathrm{C}}$ were the absorbance of sample and negative control, and $A_{\mathrm{SB}}$ and $A_{\mathrm{CB}}$ were the absorbance of sample and control blanks.

\section{Lipase inhibition assay}

The lipase inhibitory activity was assayed as described by Shimura et al. ${ }^{(28)}$ using 4-methylumbelliferyl oleate as the substrate, except that the porcine pancreatic lipase (Sigma type II) was prepared using a concentration of $0.085 \mathrm{~g} / \mathrm{ml}$. The relative lipase inhibition activity was calculated using the following formula:

Percentage of inhibition $=\left(1-\left(F_{\mathrm{S}}-F_{\mathrm{SB}}\right) /\left(F_{\mathrm{C}}-F_{\mathrm{CB}}\right)\right) \times 100$

where $F_{\mathrm{S}}$ and $F_{\mathrm{C}}$ were the values of samples and negative control measured fluorometrically at an emission wavelength of $450 \mathrm{~nm}$ and excitation of $320 \mathrm{~nm}$ by a Varian Cary Eclipse
Fluorescence Spectrophotometer (Agilent Technologies), and $F_{\mathrm{SB}}$ and $F_{\mathrm{CB}}$ were the fluorescence readings of sample and control blanks.

\section{Statistical analysis}

The significant differences between mean values were calculated based on at least three independent evaluations ( $n$ 3) and the standard deviations were also calculated. Student's $t$ test was conducted to assess differences between the samples at the level of $P<0 \cdot 05$. All half maximal inhibitory concentration $\left(\mathrm{IC}_{50}\right.$ ) values were calculated from the corresponding dose inhibition curve according to their best-fit shapes based on at least four reaction points using Microsoft Excel (Microsoft Corp, USA). Statistical correlation analyses were performed using Graphpad Prism 5 (Graphpad Software). Results for correlation analysis were considered statistically significant when $P<0 \cdot 05$.

\section{Results and discussion \\ Total phenolic content, total flavonoid content and antioxidant capacities}

The effects of roasting on TPC, TFC and antioxidant capacity of the extracts from three faba bean genotypes are presented in Table 1. In comparison to the raw sample, a higher extraction yield was obtained for the roasted samples (approximately $10 \%$ higher). The difference between the genotypes with

Table 1. Extraction yield, total phenolic content, total flavonoid content, diphenylpicrylhydrazyl (DPPH) radical scavenging activity, Trolox equivalent antioxidant capacity (TEAC) and oxygen radical absorbance capacity (ORAC) of crude extracts from the raw and roasted faba bean genotypes

\begin{tabular}{|c|c|c|c|c|}
\hline & \multicolumn{2}{|c|}{ Raw bean } & \multicolumn{2}{|c|}{ Roasted bean } \\
\hline & Mean & SD & Mean & SD \\
\hline \multicolumn{5}{|c|}{ Extraction yield (mg of extracts/DW) } \\
\hline Nura & $77 \cdot 06^{\mathrm{a}}$ & 0.60 & $83 \cdot 92^{a, b}$ & 3.19 \\
\hline Rossa & $83 \cdot 19^{\mathrm{a}, \mathrm{b}}$ & 0.34 & $90 \cdot 41^{\mathrm{b}}$ & 4.83 \\
\hline$T F\left(I c^{*} A s\right)^{*} 483 / 13$ & $78 \cdot 70^{\mathrm{a}}$ & 0.42 & $88 \cdot 51^{\mathrm{b}}$ & 1.41 \\
\hline \multicolumn{5}{|c|}{ Total phenolic content (mg GAEq/g DW) } \\
\hline Nura & $10 \cdot 68^{\mathrm{a}}$ & 0.32 & $5 \cdot 24^{\mathrm{c}}$ & 0.62 \\
\hline Rossa & $11 \cdot 26^{\mathrm{a}}$ & 0.19 & $6 \cdot 38^{\mathrm{C}}$ & 1.44 \\
\hline$T F\left(I c^{*} A s\right)^{*} 483 / 13$ & $2 \cdot 97^{\mathrm{b}}$ & 0.44 & $3.35^{\mathrm{b}}$ & 0.20 \\
\hline \multicolumn{5}{|c|}{ Total flavonoid content (mg CEq/g DW) } \\
\hline Nura & $2 \cdot 85^{\mathrm{a}}$ & $0 \cdot 13$ & $1.77^{\mathrm{C}}$ & 0.14 \\
\hline Rossa & $2 \cdot 95^{\mathrm{a}}$ & 0.15 & $2 \cdot 09^{d}$ & 0.09 \\
\hline$T F\left(I c{ }^{*} A s\right)^{*} 483 / 13$ & $1.01^{\mathrm{b}}$ & 0.01 & $0.95^{\mathrm{b}}$ & 0.11 \\
\hline \multicolumn{5}{|c|}{ DPPH radical scavenging activity ( $\mu \mathrm{mol} \mathrm{TE} / \mathrm{g} \mathrm{DW}$ ) } \\
\hline Nura & $53.37^{\mathrm{a}}$ & 1.22 & $34 \cdot 34^{\mathrm{d}}$ & 1.69 \\
\hline Rossa & $48 \cdot 11^{\mathrm{b}}$ & $3 \cdot 16$ & $37 \cdot 34^{\mathrm{d}}$ & $2 \cdot 45$ \\
\hline$T F\left(I c^{*} A s\right) * 483 / 13$ & $7 \cdot 47^{\mathrm{c}}$ & 0.26 & $9.59^{\mathrm{C}}$ & 0.99 \\
\hline \multicolumn{5}{|l|}{ TEAC ( $\mu \mathrm{mol}$ TE/g DW) } \\
\hline Nura & $72 \cdot 69^{a}$ & $2 \cdot 86$ & $49 \cdot 75^{\mathrm{c}}$ & 1.79 \\
\hline Rossa & $71 \cdot 28^{\mathrm{a}}$ & $7 \cdot 72$ & $55.95^{\mathrm{d}}$ & 2.79 \\
\hline $\operatorname{TF}\left(I c^{*} A s\right)^{*} 483 / 13$ & $25 \cdot 63^{\mathrm{b}}$ & 0.09 & $35 \cdot 81^{\mathrm{e}}$ & 3.46 \\
\hline \multicolumn{5}{|c|}{ ORAC ( $\mu \mathrm{mol}$ TE/g DW) } \\
\hline Nura & $109 \cdot 10^{a, b}$ & 11.05 & $94.43^{\mathrm{b}, \mathrm{c}}$ & 11.02 \\
\hline Rossa & $142 \cdot 80^{\mathrm{e}}$ & $11 \cdot 19$ & $116 \cdot 90^{\mathrm{a}}$ & $9 \cdot 61$ \\
\hline $\operatorname{TF}\left(I c^{*} A s\right) * 483 / 13$ & $78 \cdot 21^{\mathrm{c}, \mathrm{d}}$ & $4 \cdot 17$ & $73.91^{d}$ & 4.92 \\
\hline
\end{tabular}

(Mean values and standard deviations of at least three independent measurements, $n 3$ )

DW, dry weight; GAEq, gallic acid equivalents; CEq, catechin equivalents; TE, Trolox equivalents.

$\mathrm{a}, \mathrm{b}, \mathrm{c}, \mathrm{d}, \mathrm{e}$ Mean values with unlike superscript letters were significantly different in the respective assays $(P<0 \cdot 05)$. 
regards to the extraction yield was negligible. The level of TPC and TFC of Rossa was not significantly different from Nura in both of their raw and roasted beans, except that the roasted Rossa had slightly higher TFC than the roasted Nura. The TPC in the raw beans of coloured genotypes were about four times, while the TFC was about three times higher than TF(Ic*As)*483/13. After roasting, the TPC and TFC contents of Nura and Rossa were about two times higher than $T F\left(I c^{*} A s\right)^{*} 483 / 13$. The white-coloured $T F\left(I c^{*} A s\right) * 483 / 13$ (termed 'tannin free'), was developed for its low tannin content, thus explaining the low TPC and TFC detected in the present study.

Roasting led to a $40-50 \%$ decrease in the TPC, and a 30-40\% decrease in the TFC of both genotypes, Nura and Rossa. On the other hand, roasting only reduced the TPC and TFC of $\operatorname{TF}\left(I^{*} A s\right) * 483 / 13$ by 13 and $7 \%$, respectively. These results support earlier findings that heating applied through various cooking methods decreased the phenolic contents in different types of legumes ${ }^{(42)}$.

The antioxidant capacities of faba beans were evaluated using three assays: DPPH, TEAC and ORAC (Table 1). The antioxidant capacities of Nura and Rossa were comparable in all assays. However, the antioxidant capacity of $T F\left(I C^{*} A s\right) * 483 /$ 13 was lower than the antioxidant capacities of the other two genotypes; about two to three times (ORAC and TEAC assays, respectively) and six times lower (DPPH assay). A significant decrease in the antioxidant capacity of Rossa and Nura occurred after roasting. However, roasting did not affect the antioxidant activity of $\operatorname{TF}(I C * A s) * 483 / 13$ significantly as tested by the DPPH and ORAC assays.

A high correlation was observed for the TPC with TFC (0.98, $P<0.001)$ and the antioxidant capacities, as evaluated using DPPH (0.93, $P<0.01)$, TEAC (0.96, $P<0.01)$ and ORAC (0.87, $P<0.05)$ assays. The HPLC-post column derivatisation profiles of crude extracts detectable at $280 \mathrm{~nm}$ from the raw beans of three genotypes (Fig. 1) showed that the phenolic compounds eluted in two separate regions, which can be arbitrarily classified as relatively polar $(0-15 \mathrm{~min})$ and less polar $(15-40 \mathrm{~min})$ regions. The HPLC-post column derivatisation results also showed that most of the antioxidant activities in Rossa and Nura were contributed by the less polar region. Distinct active peaks in the less polar region were observed in the HPLC chromatograms of Nura (Fig. 1(A)) and Rossa (Fig. 1(B)). Moreover, traces of anthocyanins were also detected $(520 \mathrm{~nm}$, data not presented) in the extract from Rossa, which may contribute to the antioxidant capacity. In contrary, the HPLC chromatogram of the extract from $\operatorname{TF}\left(I c^{*} A s\right) * 483 / 13$ (Fig. 1(C)) lacked active compounds in the relatively less polar region. However, the three genotypes appeared to have similar HPLC-post column derivatisation profiles in the relatively polar region.

Faba beans with coloured seed coat were reported to contain low and high molecular weight phenolic compounds such as flavanols and proanthocyanidins ${ }^{(18)}$. The high molecular weight compounds were likely to appear at the relatively less polar region in the HPLC-post column derivatisation profiles (Fig. 1(A) and (B)) and contribute to the antioxidant capacity. High molecular weight phenolic compounds were reported
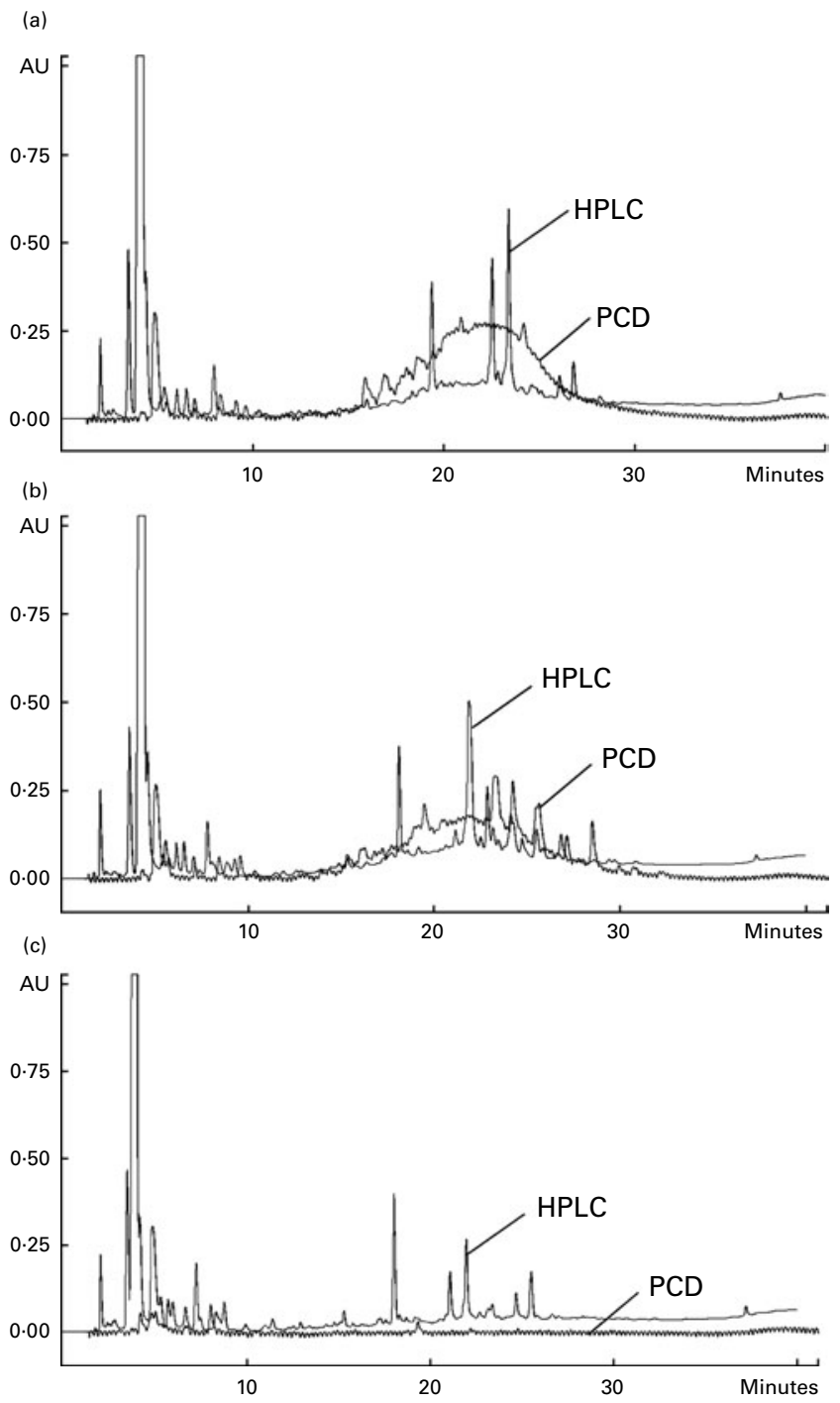

Fig. 1. Chromatograms of HPLC and on-line post column derivatisation (PCD) assay of crude extracts obtained from the raw faba bean genotypes: (A) Nura, (B) Rossa and (C) $\operatorname{TF}\left(I c^{\star} A s\right)^{*} 483 / 13$.

previously to be very active hydrogen donors, and thereby radical quenchers ${ }^{(43)}$. The white-coloured TF(IC*As)*483/13 contained noticeably lower TPC and TFC, and subsequently exhibited significantly lower antioxidant capacity. The HPLC chromatogram of extract from $\operatorname{TF}\left(I^{*} A s\right) * 483 / 13$ (Fig. 1(C)) showed a lack of active phenolic compounds at the less polar region, which might be the polymeric compounds. The present results confirm earlier findings by Madhujith et $a l .{ }^{(29)}$, who also were not able to detect anthocyanidin and procyanidin in the white bean varieties.

\section{Cellular protection by faba bean extracts}

Cellular antioxidant activity assay. The CAA assay evaluates antioxidant activity at the cellular level. The final result of this assay depends on uptake, distribution and metabolism of the antioxidant compounds in a live cell. This information cannot 
Table 2. Cellular antioxidant activity of the crude extracts obtained from the raw and roasted faba bean genotypes, Nura and Rossa

(Mean values and standard deviations of three independent experiments, $n$ 3)

\begin{tabular}{|c|c|c|c|c|}
\hline \multirow[b]{3}{*}{ Faba bean genotype } & \multicolumn{4}{|c|}{ Cellular antioxidant activity } \\
\hline & \multicolumn{2}{|c|}{$\mu \mathrm{mol}$ QE/g DW } & \multicolumn{2}{|c|}{$\mathrm{EC}_{50}(\mu \mathrm{g} / \mathrm{ml})^{*}$} \\
\hline & Mean & SD & Mean & SD \\
\hline \multicolumn{5}{|l|}{ Raw bean } \\
\hline Nura & $7 \cdot 8^{\mathrm{a}}$ & 0.5 & $402 \cdot 3$ & $27 \cdot 1$ \\
\hline Rossa & $15 \cdot 8^{\mathrm{a}}$ & $4 \cdot 2$ & $208 \cdot 0$ & $60 \cdot 4$ \\
\hline \multicolumn{5}{|l|}{ Roasted bean } \\
\hline Nura & $8 \cdot 9^{a}$ & 6.5 & $277 \cdot 8$ & $69 \cdot 7$ \\
\hline Rossa & $13 \cdot 9^{\mathrm{a}}$ & $4 \cdot 2$ & 241.3 & $73 \cdot 1$ \\
\hline
\end{tabular}

$\mu \mathrm{mol} \mathrm{QE} / \mathrm{g} \mathrm{DW}, \mu \mathrm{mol}$ quercetin equivalents per $\mathrm{g}$ of bean (dry weight basis); $\mathrm{EC}_{50}$ half maximal effective concentration.

${ }^{a}$ Mean values with same superscript letters were not significantly different.

${ }^{*}$ Concentration of the lyophilised extract in the culture medium $(\mu \mathrm{g} / \mathrm{ml})$ able to scavenge $50 \%$ of free radicals effectively within a cell.

be obtained in a reagent-based antioxidant testing. In comparison to animal models, the CAA is a cost-effective and fast way to obtain important information on the efficiency of antioxidants within a cell ${ }^{(40)}$. Extracts from Nura and Rossa were evaluated in this study. No significant difference was found between the CAA of extracts obtained from both genotypes, regardless of heat treatment, as expressed in $\mu \mathrm{mol}$ quercetin equivalent $/ \mathrm{g}$ dry weight of bean (Table 2). However, half maximal effective concentration $\left(\mathrm{EC}_{50}\right)$ of the roasted Nura showed a tendency for a higher uptake of extracts than its raw beans. The HPLC chromatogram (Fig. 1) demonstrated compositional differences between the compounds detected at $280 \mathrm{~nm}$ in extracts from Nura and Rossa. The 'hump' at the less polar region dominated in extracts from both Nura and Rossa could be the polymeric compounds, while phenolic acids and flavonols were greater in the extract from Rossa (data not presented). A variety of phenolic compositions were likely to contribute to the different cell uptake rates and efficiency of protection against peroxyl radicals, within an hour. It can also be speculated that heat application during roasting of faba beans caused a partial oxidation of polymeric compounds which would affect the uptake and reflect on the antioxidant capacity within a cell. The CAA EC 50 values of the faba beans are slightly lower than those of lentil $(670 \mu \mathrm{g} / \mathrm{ml})$, yellow pea $(780 \mu \mathrm{g} / \mathrm{ml})$ and green peas $(1280 \mu \mathrm{g} / \mathrm{ml})$ as reported in Xu \& Chang ${ }^{(44)}$ assayed using AGS cells.

Cellular protection against $\mathrm{H}_{2} \mathrm{O}_{2} . \mathrm{H}_{2} \mathrm{O}_{2}$ is a reactive oxygen species which is present in live cells and is used in experimental models. In this experimental model, we evaluated the protective effect of the faba bean extracts against $\mathrm{H}_{2} \mathrm{O}_{2-}$ induced apoptosis in RAW264.7 cells (Fig. 2). Extracts obtained from the raw faba bean genotypes, Nura and Rossa, were applied at concentrations of $0 \cdot 1-0 \cdot 4 \mathrm{mg} / \mathrm{ml}$, and exhibited cellular protection against $\mathrm{H}_{2} \mathrm{O}_{2}$ in a dose-dependent manner (Fig. 2(A) and (C)). However, the protection diminished at concentrations higher than $0.4 \mathrm{mg} / \mathrm{ml}$ due to the commencement of
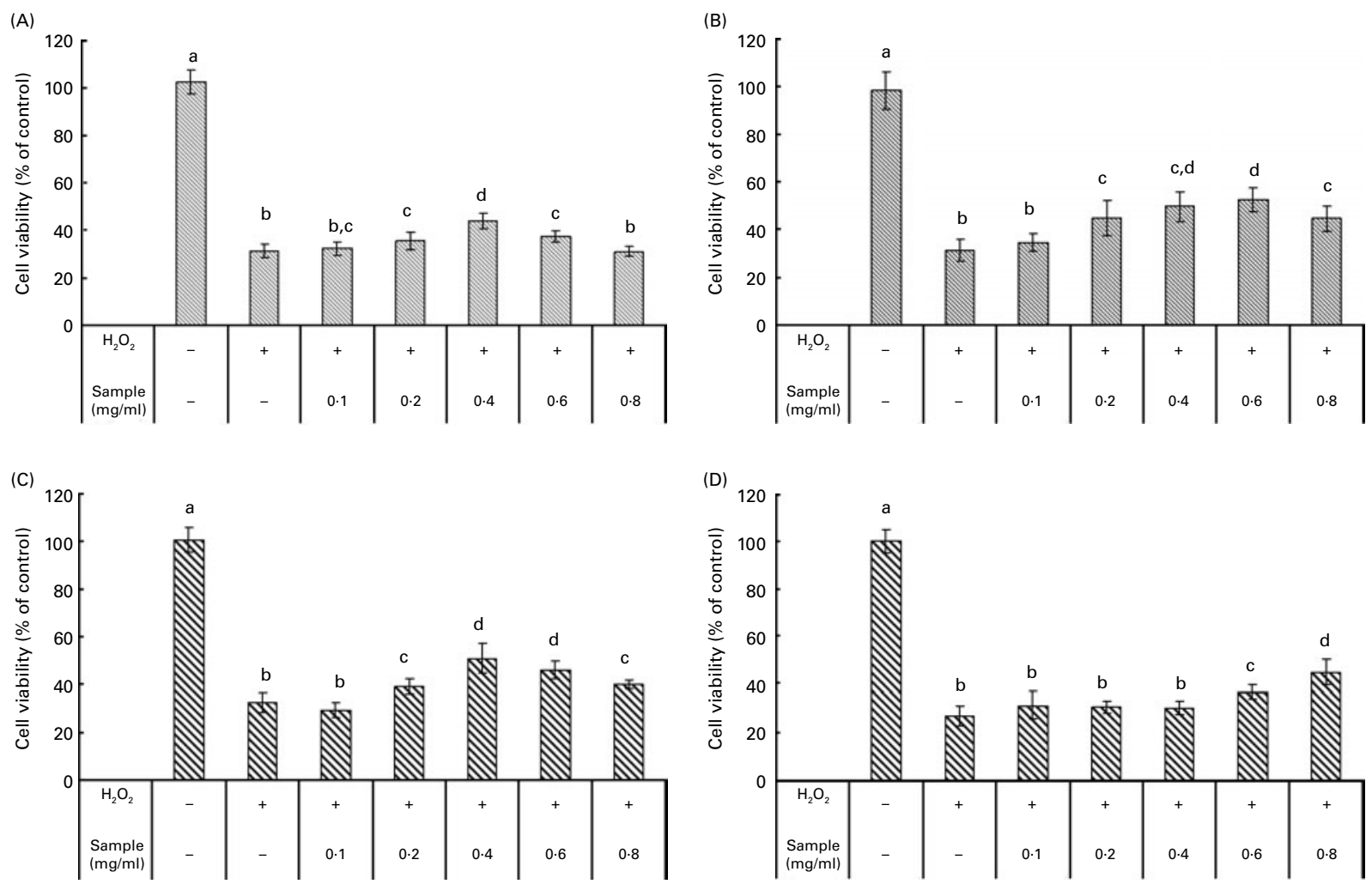

Fig. 2. Cellular protection against $\mathrm{H}_{2} \mathrm{O}_{2}(40 \mathrm{~mm})$ on RAW264.7 cells by crude extracts obtained from the (A) raw and (B) roasted Nura; (C) raw and (D) roasted Rossa. Values are means of four replicates, with standard deviations represented by vertical bars. ${ }^{\text {a,b,c,d }}$ Mean values with unlike letters were significantly different $(P<0.05)$. 
Table 3. Effects of faba bean crude extracts on the proliferation of human cancer cells: AGS, BL13, Hep G2 and nontransformed cells: CCD-18 Co

(Mean values and standard deviations)

\begin{tabular}{|c|c|c|c|c|c|c|c|c|c|c|}
\hline \multirow[b]{3}{*}{ Faba bean genotype } & \multicolumn{10}{|c|}{$\mathrm{IC}_{50}{ }^{*}(\mathrm{mg} / \mathrm{ml})$} \\
\hline & \multicolumn{2}{|c|}{ AGS (gastric) } & \multicolumn{2}{|c|}{ BL13 (bladder) } & \multicolumn{2}{|c|}{ Hep G2 (liver) } & \multicolumn{2}{|c|}{ HT-29 (colon) } & \multicolumn{2}{|c|}{$\begin{array}{l}\text { CCD-18Co } \\
\text { (colon) }\end{array}$} \\
\hline & Mean & SD & Mean & SD & Mean & SD & Mean & SD & Mean & SD \\
\hline \multicolumn{11}{|l|}{ Raw bean } \\
\hline Nura & $<0.2$ & - & 1.90 & 0.15 & $<0.2$ & - & 1.46 & 0.06 & $>2$ & - \\
\hline Rossa & 1.04 & 0.06 & 2.33 & 0.18 & 1.59 & 0.06 & 1.37 & 0.07 & $>2$ & - \\
\hline \multicolumn{11}{|l|}{ Roasted bean } \\
\hline Nura & 1.64 & 0.05 & 1.74 & 0.06 & 1.55 & 0.34 & 1.45 & 0.06 & $>2$ & - \\
\hline Rossa & 2.03 & 0.05 & 1.74 & 0.09 & 1.60 & 0.07 & 1.87 & 0.04 & $>2$ & - \\
\hline
\end{tabular}

$\mathrm{IC}_{50}$, half maximal inhibitory concentration.

${ }^{*}$ Results were presented as concentration $(\mathrm{mg} / \mathrm{ml})$ of crude extracts in the culture medium needed to achieve suppression of cell growth by $50 \%\left(\mathrm{IC}_{50}\right)$. Sample concentration ranged from 0.2 to $2.0 \mathrm{mg} / \mathrm{ml}$. The results were obtained via nonlinear regression and based on at least four replicates.

antiproliferative effects, or possibly due to the pro-oxidative effects of phenolic compounds at high concentrations. The pro-oxidative effect might be caused by the interaction of the added phenolic compounds with undefined components from the culture media, resulting in the generation of $\mathrm{H}_{2} \mathrm{O}_{2}^{(45)}$. The same tendency was observed for extracts obtained from the roasted Nura (Fig. 2(B)). On the other hand, the protective effects by extracts obtained from the roasted Nura and Rossa were observed at concentrations at 0.2 and $0.6 \mathrm{mg} / \mathrm{ml}$, respectively (Fig. 2(B) and (D)). In comparison to other results on the protection of RAW264.7 cells from $\mathrm{H}_{2} \mathrm{O}_{2}$-induced injury, the faba bean extracts appeared less efficient than that of Kakadu plum extract ${ }^{(39)}$. However, the crude faba bean extracts were used for this study, whereas purified and concentrated Kakadu plum extracts (using XAD-7 resin column) were used. Chow et al. ${ }^{(46)}$ found that 25 and $50 \mu \mathrm{m}$ of quercetin (but not rutin and quercitrin) posed potent protection of RAW264.7 cells against $\mathrm{H}_{2} \mathrm{O}_{2}$-induced injury.

\section{Effects of faba bean extracts on proliferation and apoptosis} of cancer cells

The effect of extracts obtained from the raw and roasted faba bean genotypes, Nura and Rossa, on the proliferation of different types of cancer cells including AGS, HT-29, BL13, Hep G2 and one non-transformed cell line, CCD-18Co, is presented in Table 3. The crude faba bean extracts, applied at a concentration range of $0 \cdot 2-2 \cdot 0 \mathrm{mg} / \mathrm{ml}$, exhibited a dose-dependent suppression of all of the tested human cancer cell proliferations, while exhibiting negligible proliferation effect on the non-transformed human colon CCD-18Co cells. Extracts from the raw Nura suppressed some proliferation of non-transformed colon cells, CCD-18Co, while the raw Rossa did not (Fig. 3(A)). Extracts from raw beans of both genotypes effectively suppressed proliferation of the human colon cancer cells, HT-29 (Fig. 3(B)). On the other hand, extracts from the roasted Nura and Rossa did not affect the proliferation of the non-transformed CCD-18Co cells (Fig. 4(A)), but effectively suppressed the proliferation of the human colon cancer cells, HT-29 (Fig. 4(B))
Heating appeared to cause decreases in phenolic contents and antioxidant capacities, which were in line with some but not all of the antiproliferation results. This suggests that different types of phenolic compounds in the faba bean extracts might exert a diverse degree of activities on specific target sites of cells. The $\mathrm{IC}_{50}$ value represents the concentration required to inhibit $50 \%$ of cell proliferation, and therefore, a lower $\mathrm{IC}_{50}$ indicates a greater antiproliferation ability. The $\mathrm{IC}_{50}$ values of extract from the raw Nura $(<0 \cdot 2 \mathrm{mg} / \mathrm{ml})$ and
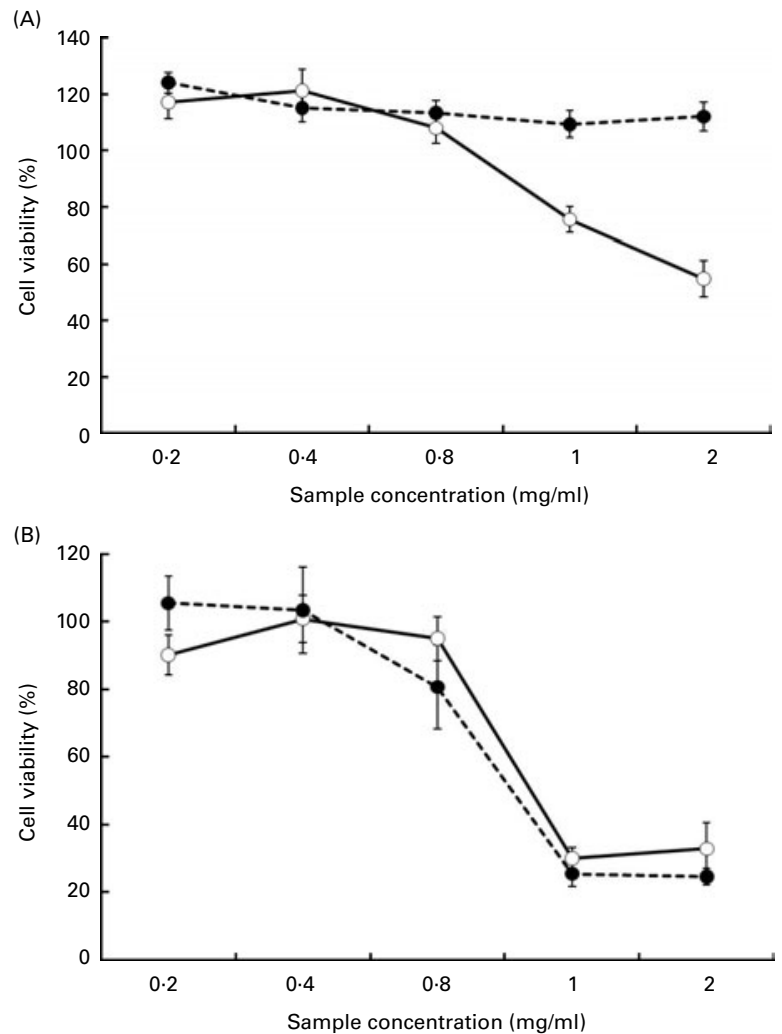

Fig. 3. The effect of crude extracts obtained from the raw faba bean genotypes, Nura (-O) and Rossa (.-.) on proliferation of (A) non-transformed human colon cells, CCD-18Co and (B) human colon cancer cells, HT-29. Values are means of at least three independent experiments with four replicates, with standard deviations represented by vertical bars, $n 4$. 

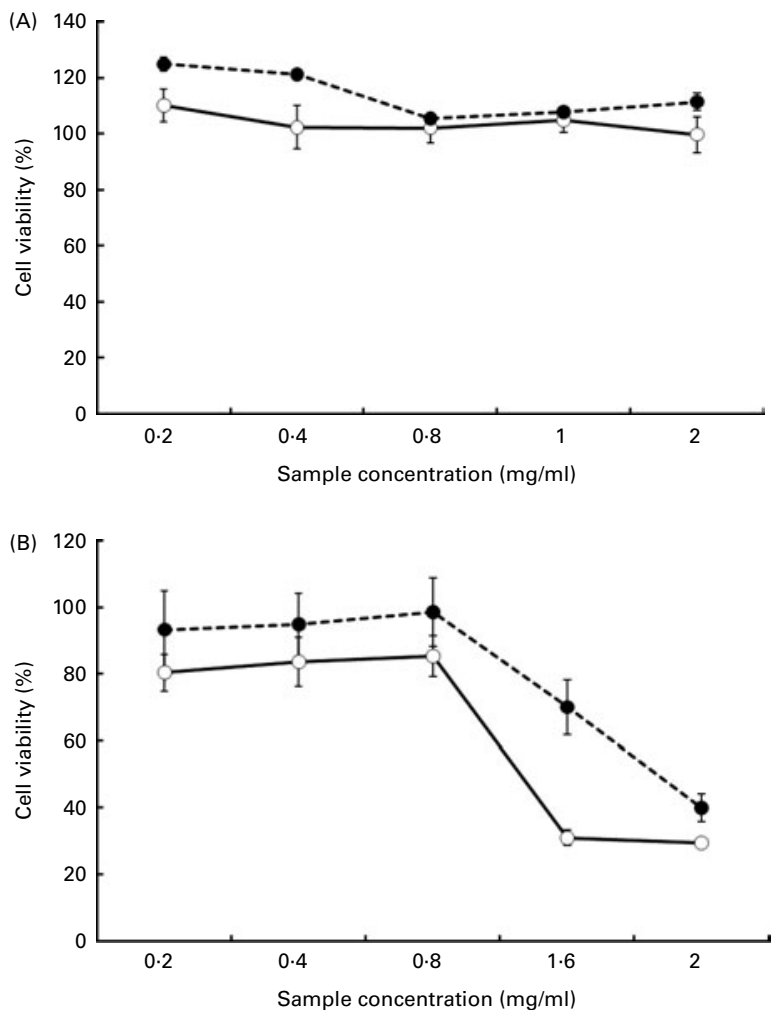

Fig. 4. The effect of crude extracts obtained from the roasted faba bean genotypes, Nura (-O-) and Rossa (--.-) on proliferation of (A) non-transformed human colon cells, CCD-18Co and (B) human colon cancer cells, HT-29. Values are means of at least three independent experiments with four replicates, with standard deviations represented by vertical bars, $n 4$.

Rossa $(1.04 \mathrm{mg} / \mathrm{ml})$ were lower than green pea $(3.25 \mathrm{mg} / \mathrm{ml})$, chickpea $(3.23 \mathrm{mg} / \mathrm{ml})$ and lentil $(1.27 \mathrm{mg} / \mathrm{ml})$ as tested on AGS cells ${ }^{(44)}$. Seeram et $a l^{(47)}$ found that different cancer cell lines had diverse levels of sensitivity to phenolic compounds extracted from cranberries using different cell viability testing assays. Extracts from the raw Nura posed exceptionally high antiproliferative effects on AGS and Hep G2 cells in comparison to the raw Rossa. The reason is not known and the results are under further investigation. However, in support of our findings, the $\mathrm{IC}_{50}$ values of six types of berry extracts tested on six different human tumour cell lines were all reported to be less than $0 \cdot 2 \mathrm{mg} / \mathrm{ml}^{(48)}$

In order to understand the mechanism behind the suppression of cancer cell proliferation, an investigation to identify apoptotic and necrotic cells within the populations treated by the faba bean extracts was carried out. Apoptosis is a natural cell death process which cancer cells evade. Induction of apoptosis in cancer cells is the preferred way to remove them from the human body, which is an approach used in chemotherapy treatments ${ }^{(49)}$. Food compounds that are able to induce apoptosis of cancer cells might contribute to cancer prevention.

The flow cytometric analysis revealed that exposure of HL-60 (human promyelocytic leukaemia cells) to crude extracts obtained from the raw and roasted faba bean genotypes, Nura and Rossa, induced cell apoptosis (Fig. 5). The percentage of apoptotic cells increased with greater extract concentrations
(Fig. 5(A)). After the first $3 \mathrm{~h}$ of incubation, early apoptotic events were detected. The number of apoptotic cells increased over the treatment time (Fig. 5(B)), with the greatest percentage of apoptotic cells induced by both, the raw and roasted faba bean extracts, over $24 \mathrm{~h}$. In addition, the percentage of necrotic cells remained very low. This result suggests that the suppression of cancer cell proliferation was due to induction of apoptosis by the applied faba bean extracts

\section{Inhibition of angiotensin-converting enzyme, $\alpha$-glucosidase and lipase}

ACE is a key blood pressure regulator which is responsible for vasoconstriction that leads to an increase in blood pressure. Inhibition of ACE activity can potentially prevent ACE from elevating blood pressure, reducing the incidence of hypertension. The enzymes, $\alpha$-glucosidase and lipase are important enzymes in the digestive tract and are responsible for sugar and lipid digestion, respectively. Inhibition of $\alpha$-glucosidase activity could potentially reduce starch digestion and sugar absorption, therefore contributing to a lower postprandial hyperglycaemic response, whereas the inhibition of lipase activity could reduce fat uptake contributing to weight maintenance.

The raw and roasted faba bean extracts inhibited the activity of all the investigated enzymes. Condensed tannins
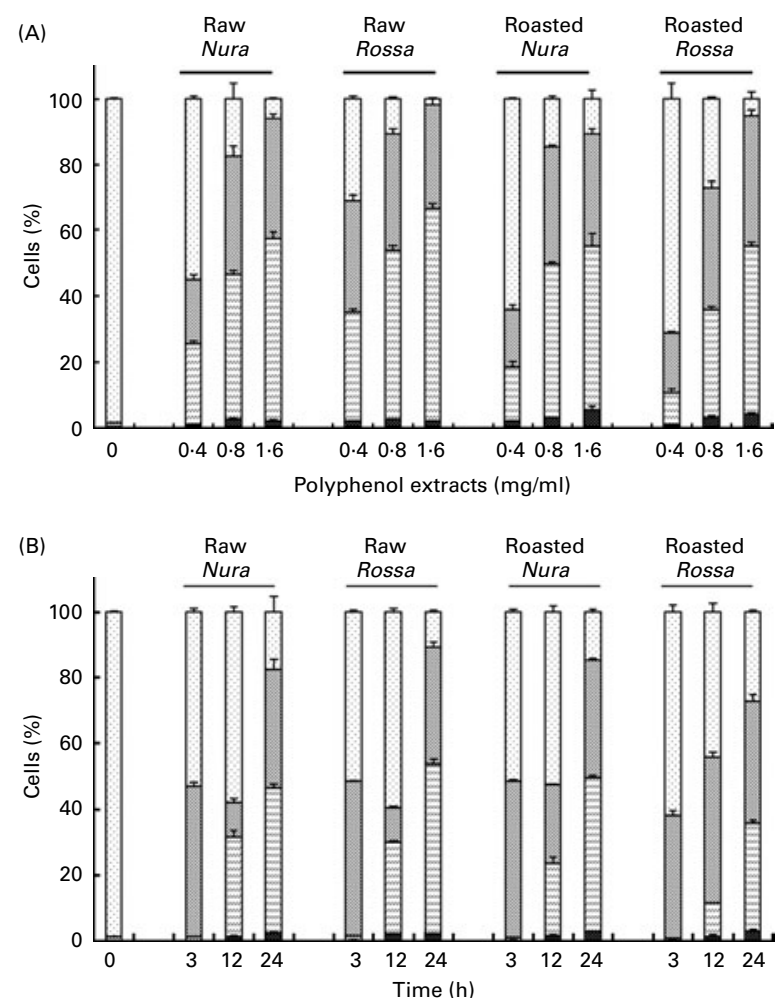

Fig. 5. Apoptosis of human leukaemia cells, HL-60, induced by crude extracts obtained from the raw and roasted faba beans as determined by flow cytometric analysis based on (A) different dose-response and $(B)$ time course (extract concentration: $0.8 \mathrm{mg} / \mathrm{mL}$ ). Values are means of three independent flow cytometric analysis for 3000-10000 cells in each population and presented as a percentage of each cell population, with standard deviations represented by vertical bars, $n 3$. Necrotic cells; $⿴$, late apoptotic cells; $₫$, early apoptotic cells; $\mathrm{\theta}$, viable cells. 


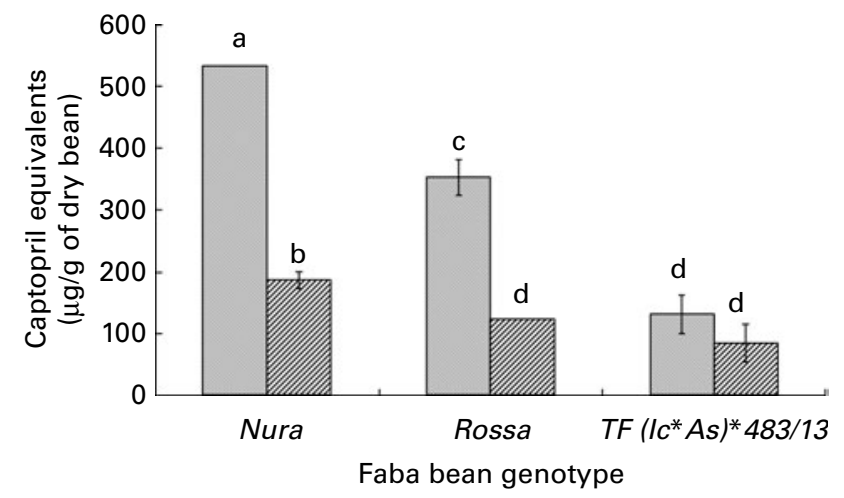

Fig. 6. Angiotensin-converting enzyme inhibition by crude extracts obtained from the raw $(\nabla)$ and roasted $(\square)$ faba bean genotypes. Results were expressed as $\mu \mathrm{g}$ of captopril equivalents/g of dry weight of beans. Values are means, with standard deviations represented by vertical bars, $n 3$. a,b,c,d Mean values with unlike letters were significantly different $(P<0.05)$.

(proanthocyanidins) in faba beans are prone to forming complexes with proteins ${ }^{(50)}$. Therefore, the observed inhibition of the various enzymes investigated in the present study is probably due to the formation of proanthocyanidin-enzyme complexes $^{(51)}$.

Extracts from Nura exhibited the greatest ACE inhibition activity in both of the raw and roasted beans, followed by extracts from Rossa and TF(IC*As)*483/13 (Fig. 6). Unfortunately, roasting reduced ACE inhibition activity in the faba beans significantly, except for $T F\left(I^{*} A s\right)^{*} 483 / 13$.

Roasting was found to decrease the level of $\alpha$-glucosidase inhibitory activity of all the investigated genotypes (Table 4). Among extracts obtained from both of the raw and roasted beans, Rossa exhibited the highest $\alpha$-glucosidase inhibition activity, followed by Nura and $T F\left(I C^{*} A s\right) * 483 / 13$. Similar decreases of $\alpha$-glucosidase inhibitory activities after thermal processing in most of the coloured bean genotypes were also reported by Ranilla et al. ${ }^{(8)}$.

Extracts from Rossa exhibited the strongest lipase inhibitory activity followed by Nura and TF(IC*As)*483/13 (Table 5).

Table 4. Effects of roasting on the $\alpha$-glucosidase inhibitory activity of faba bean crude extracts

(Mean values and standard deviations, $n 3$ )

\begin{tabular}{llr}
\hline & \multicolumn{2}{c}{$\alpha$-Glucosidase inhibition $(\%)^{*}$} \\
\cline { 2 - 3 } Faba bean genotype & Mean & SD \\
\hline Raw bean & & \\
$\quad$ Nura & 63.10 & 0.49 \\
$\quad$ Rossa & 68.28 & 1.95 \\
$\quad T F\left(I c^{*} A s\right)^{*} 483 / 13$ & 59.66 & 0.49 \\
Roasted bean & & \\
$\quad$ Nura & 30.00 & 0.49 \\
$\quad$ Rossa & 44.14 & 0.98 \\
$\quad T F\left(I C^{*} A s\right)^{*} 483 / 13$ & 19.31 & 2.93 \\
Reference sample & & \\
$\quad$ Acarbose & 85.96 & 3.79 \\
\hline
\end{tabular}

* Relative $\alpha$-glucosidase inhibition activities of crude extracts from the raw and roasted faba bean genotypes. Results were based on the averages of three determinations. The concentrations of the samples (including the reference sample) used were set at $2 \mathrm{mg} / \mathrm{ml}$.
Table 5. Half maximal inhibitory concentration $\left(\mathrm{IC}_{50}\right)$ and relative lipase inhibitory activity of crude extracts from the raw and roasted faba bean genotypes

(Mean values and standard deviations, $n 3$ )

\begin{tabular}{|c|c|c|c|}
\hline \multirow[b]{3}{*}{ Faba bean genotype } & \multicolumn{2}{|c|}{ Lipase inhibition } & \multirow[b]{3}{*}{$\mathrm{IC}_{50}(\mathrm{mg} / \mathrm{ml}) \dagger$} \\
\hline & \multicolumn{2}{|c|}{ Relative percentage ${ }^{*}$} & \\
\hline & Mean & SD & \\
\hline \multicolumn{4}{|l|}{ Raw } \\
\hline Nura & $21 \cdot 28$ & $1 \cdot 61$ & 81.43 \\
\hline Rossa & $48 \cdot 15$ & 1.87 & $43 \cdot 28$ \\
\hline$T F(I c * A s)^{\star} 483 / 13$ & 18.55 & $2 \cdot 67$ & $105 \cdot 60$ \\
\hline \multicolumn{4}{|l|}{ Roasted } \\
\hline Nura & 34.00 & 0.78 & $70 \cdot 26$ \\
\hline Rossa & $55 \cdot 24$ & $2 \cdot 56$ & $40 \cdot 72$ \\
\hline$T F\left(I c{ }^{*} A s^{*} 483 / 13\right.$ & $30 \cdot 08$ & 2.96 & $72 \cdot 17$ \\
\hline
\end{tabular}

* Relative lipase inhibitory activity of crude extracts from the raw and roasted faba bean genotypes. Results were based on an average of three determinations. The sample concentrations were set at $40 \mathrm{mg} / \mathrm{ml}$.

$\dagger$ The final concentration of faba bean crude extracts required to achieve the inhibition of enzymatic activity by $50 \%$ under assay condition.

In contrary to the results of roasting effect on the other types of enzymes, heating was found to cause an increase in lipase inhibitory activity in all faba bean genotypes. Similar to the present results, Zadernowski et al. ${ }^{(51)}$ also reported lipase inhibition activity in both faba bean and pea varieties.

The Pearson's correlation disclosed that ACE results were positively correlated with the TPC (0.88), TFC (0.83), DPPH radical scavenging activity (0.81) and TEAC (0.81) results $(P<0.05)$, but not significantly correlated with the ORAC results (0.55, $P=0.26)$. The data suggest that ACE inhibition of faba bean extracts might be caused by the phenolic compounds. In contrary, the results of $\alpha$-glucosidase and lipase inhibitory activities did not correlate with the results of other assays. Zhang et al. $^{(52)}$ also found no correlation between the TPC and $\alpha$-glucosidase inhibitory activity among the extracts of seven raspberry cultivars. This suggests that TPC were not directly related to the

$\alpha$-glucosidase and lipase inhibition activities in faba beans. Ranilla et $a l .{ }^{(8)}$ reported positive and negative correlations of the TPC with the $\alpha$-glucosidase and ACE inhibitions as being 0.24 and -0.42 , respectively, in the different dry bean cultivars. On the other hand, Silva Pinto et al. ${ }^{(53)}$ and Mai et al. ${ }^{(54)}$ who tested Brazilian strawberries and Vietnamese edible plants found positive relationships between the TPC and the $\alpha$-glucosidase inhibitory activity, respectively. This suggests that the relationship between phenolic compounds and $\alpha$-glucosidase activity depends on the phenolic compositions and subsequently could be plant-specific.

In fact, the solvent used in this study possibly extracted constituents other than phenolic compounds in faba beans, such as trypsin inhibitors ${ }^{(55)}$, oligosaccharides ${ }^{(56)}$, vicine and convicine $^{(57)}$, lipase ${ }^{(58)}$, saponins ${ }^{(59)}$ and particularly phytate which has been reported to have the ability to bind with proteins ${ }^{(60)}$, and these microconstituents might affect the results of enzyme inhibition assays. The strong bioactivities of faba bean could be a result of synergistic interaction between those constituents. 
The phenolic extracts of three faba bean genotypes exhibited significant differences in activities as evaluated using a range of in vitro assays. Therefore, the present study suggests a possible role for plant breeders to select genotypes for specific health functionality. Faba bean flour or fractionated components can be potentially incorporated into new food products as ingredients to impart desirable health benefits. It would be useful to determine the actual faba bean (or ingredient) intake required to have significant desirable health-promoting effects. However, the actual bioavailability of the phenolic compounds (especially proanthocyanidins) to humans remains unclear ${ }^{(61,62)}$. Therefore, further research is required to (1) identify these native compounds and their metabolic products and (2) examine their effects on the human digestive system (e.g. metabolised by the colonic microflora) through human clinical studies, before drawing a final conclusion on the faba bean polyphenols in relation to human health.

\section{Conclusions}

The crude phenolic extracts obtained from the raw and roasted faba beans evaluated in the present study exhibited potential health-benefiting properties, including potent antioxidant activities (based on both reagent- and cell-based assays), chemopreventative effects (through induction of cancer cell apoptosis) and protection against reactive oxygen species, $\mathrm{H}_{2} \mathrm{O}_{2}$. In addition, these extracts showed inhibitory effect on ACE, $\alpha$-glucosidase and lipase as studied using in vitro methods. Faba bean extracts suppressed proliferation of different types of cancer cells in a dose-dependent manner, but posed negligible effect on the CCD-18Co (colon normal) cells particularly after roasting. According to the reagent-based assays, roasting decreased the antioxidant activities of faba bean extracts; however, the roasting effect on cellular and enzymatic assays varied. Overall, Nura (buff-coloured) and Rossa (red-coloured) exhibited comparable functional properties, while $T F\left(I c^{*} A s\right)^{*} 483 / 13$ (whitecoloured) contained the lowest level of all tested functional properties. The present study encourages a wider utilisation of faba bean in human diets for its potential health benefits due to their known microconstituents, such as phenolics.

\section{Acknowledgements}

Funding for the present study was provided by Food Futures Flagship, CSIRO Food and Nutritional Sciences; Grains Research \& Development Corporation (GRDC Research Code GRS166) and EH Graham Centre for Agricultural Innovation (an alliance between Charles Sturt University and NSW Department of Primary Industries). The support received from the Charles Sturt University Postgraduate Writing-Up Award Scheme is gratefully acknowledged. The authors thank Jeffrey Paull, Peter Matthews, Eric Armstrong and Gerard O'Connor for providing samples, and Dr Michelle Bull for acquiring sample data using the flow cytometer. The order of authors reflects their relative contributions. The authors declare no conflict of interest.

\section{References}

1. Food and Agriculture Organization of the United Nations (FAO) (2009), Rome, FAOSTAT data; available at http://faostat.fao.org (Accessed November 2009).

2. Matthews P \& Marcellos H (2003) Faba bean. Agfact P4.2.7. Agfact (Serial on the Internet). The State of New South Wales, NSW Agriculture; available at http://www.dpi.nsw. gov.au/agriculture/field/field-crops/pulses/beans/faba-bean (Accessed November 2010).

3. Bouhnik Y, Flourie B, D'Agay-Abensour L, et al. (1997) Administration of transgalacto-oligosaccharides increases fecal bifidobacteria and modifies colonic fermentation metabolism in healthy human. J Nutr 127, 444-448.

4. Mathers JC (2002) Pulses and carcinogenesis: potential for the prevention of colon, breast and other cancers. Br J Nutr 88, 273-279.

5. Campos-Vega R, Loarca-Piña G \& Oomah BD (2010) Minor components of pulses and their potential impact on human health. Food Res Int 43, 461-482.

6. Aune D, De Stefani E, Ronco A, et al. (2009) Legume intake and the risk of cancer: a multisite case-control study in Uruguay. Cancer Causes Control 20, 1605-1615.

7. Anderson JW \& Major AW (2002) Pulses and lipaemia, shortand long-term effect: potential in the prevention of cardiovascular disease. Br J Nutr 88, 263-271.

8. Ranilla LG, Kwon YI, Genevese MI, et al. (2010) Effect of thermal treatment on phenolic compounds and functionality linked to type 2 diabetes and hypertension management of Peruvian and Brazilian bean cultivars (Phaseolus vulgaris L.) using in vitro methods. J Food Biochem 34, 329-355.

9. Ferguson LR (2001) Role of plant polyphenols in genomic stability. Mutat Res 475, 89-111.

10. Gomez M, Oliete B, Rosell CM, et al. (2008) Studies on cake quality made of wheat-chickpea flour blends. LWT - Food Sci Technol 41, 1701-1709.

11. Patterson CA, Maskus H \& Bassett CMC (2010) Fortifying foods with pulses. Cereal Foods World 55, 56-62.

12. Alonso R, Aguirre A \& Marzo F (2000) Effects of extrusion and traditional processing methods on antinutrients and in vitro digestibility of protein and starch in faba and kidney beans. Food Chem 68, 159-165.

13. Khalil AH \& Mansour EH (1995) The effect of cooking, autoclaving and germination on the nutritional quality of faba beans. Food Chem 54, 177-182.

14. Acar O, Gokmen V, Pellegrini N, et al. (2009) Direct evaluation of the total antioxidant capacity of raw and roasted pulses, nuts and seeds. Eur Food Res Technol 229, 961-969.

15. Anderson JC, Idowu AO, Singh U, et al. (1994) Physicochemical characteristics of flours of faba bean as influenced by processing methods. Plant Foods Hum Nutr 45, 371-379.

16. Merghem R, Jay M, Brun N, et al. (2004) Qualitative analysis and HPLC isolation and identification of procyanidins from Vicia faba. Phytochem Anal 15, 95-99.

17. Helsper JPFG, Kolodzieg H, Hoogendijk JM, et al. (1993) Antinutritional factors in faba beans (Vica faba L.) as affected by breeding toward the absence of condensed tannins. J Agric Food Chem 41, 1058-1061.

18. Borowska J, Giczewska A \& Zadernowski R (2003) Nutritional value of broad bean seeds. Part 2: selected biologically active components. Nabrung-Food 47, 98-101.

19. Arts ICW, van de Putte B \& Hollman PCH (2000) Catechin contents of foods commonly consumed in the Netherlands. 1. Fruits, vegetables, staple foods, and processed foods. J Agric Food Chem 48, 1746-1751. 
20. Hertog MGL, Hollman PCH \& Katan MB (1992) Content of potentially anticarcinogenic flavonoids of 28 vegetables and 9 fruits commonly consumed in the Netherlands. J Agric Food Chem 40, 2379-2383.

21. Kaufman PB, Duke JA, Brielmann H, et al. (1997) A comparative survey of leguminous plants as sources of the isoflavones, genistein and daidzein: implications for human nutrition and health. J Altern Complement Med 3, 7-12.

22. Sosulski FW \& Dabrowski KJ (1984) Composition of free and hydrolyzable phenolic acids in the flours and hulls of ten legume species. J Agric Food Chem 32, 131-133.

23. Moneam NMA (1990) Effects of presoaking on faba bean enzyme inhibitors and polyphenols after cooking. J Agric Food Chem 38, 1479-1482.

24. Bekkara F, Jay M, Viricel MR, et al. (1998) Distribution of phenolic compounds within seed and seedlings of two Vicia faba cvs differing in their seed tannin content, and study of their seed and root phenolic exudations. Plant Soil 203, 27-36.

25. Karamac M, Kosinska A, Rybarczyk A, et al. (2005) Extraction and chromatograhic separation of tannin fractions from tannin-rich plant material. Pol J Food Nutr Sci 57, 471-474.

26. Amarowicz R, Troszynska A, Bary Ko-Pikielna N, et al. (2004) Polyphenolics extracts from legume seeds: correlations between total antioxidant activity, total phenolics content, tannins content and astringency. J Food Lipids 11, $278-286$.

27. Ikarashi N, Takeda R, Ito K, et al. (2011) The inhibition of lipase and glucosidase activities by acacia polyphenol. Evid Based Complement Alternat Med 2011, 272075.

28. Shimura S, Tsuzuki W, Kobayashi S, et al. (1992) Inhibitory effect on lipase activity of extracts from medicinal herbs. Biosci Biotechnol Biochem 56, 1478-1479.

29. Madhujith T, Amarowicz R \& Shahidi F (2004) Phenolic antioxidants in beans and their effects on inhibition of radicalinduced DNA damage. J Am Oil Chem Soc 81, 691-696.

30. de Mejía EG, Castaño-Tostado E \& Loarca-Piña G (1999) Antimutagenic effects of natural phenolic compounds in beans. Mutat Res 441, 1-9.

31. Itoh T, Umekawa H \& Furuichi Y (2005) Potential ability of hot water adzuki (Vigna angularis) extracts to inhibit the adhesion, invasion, and metastasis of murine B16 melanoma cells. Biosci Biotechnol Biochem 69, 448-454.

32. Amarowicz R, Karamac M, Kmita-Glazewska H, et al. (1996) Antioxidant activity of phenolic fractions of everlasting pea, faba bean and broad bean. J Food Lipids 3, 199-211.

33. Kalogeropoulos N, Chiou A, Ioannou M, et al. (2010) Nutritional evaluation and bioactive microconstituents (phytosterols, tocopherols, polyphenols, triterpenic acids) in cooked dry legumes usually consumed in the Mediterranean countries. Food Chem 121, 682-690.

34. Konczak I, Zabaras D, Dunstan M, et al. (2010) Antioxidant capacity and phenolic compounds in commercially grown native Australian herbs and species. Food Chem 122, 260-266.

35. Michalska A, Ceglinska A, Amarowicz R, et al. (2007) Antioxidant contents and antioxidative properties of traditional rye breads. J Agric Food Chem 55, 734-740.

36. Prior RL, Hoang H, Gu L, et al. (2003) Assays for hydrophilic and lipophilic antioxidant capacity (oxygen radical absorbance capacity $\left(\mathrm{ORAC}_{\mathrm{FL}}\right)$ ) of plasma and other biological and food samples. J Agric Food Chem 51, 3273-3279.

37. Ee KY, Agboola S, Rehman A, et al. (2011) Characterisation of phenolic components present in raw and roasted wattle (Acacia victoriae Bentham) seed. Food Chem 129, 816-821.
38. Brookes DE, Zandvliet D, Watt F, et al. (1998) Relative activity and specificity of promoters from prostate-expressed genes. Prostate 35, 18-26.

39. Tan AC, Konczak I, Ramzan I, et al. (2011) Antioxidant and cytoprotective activities of native Australian fruit polyphenols. Food Res Int 44, 2034-2040.

40. Wolfe KL \& Liu RH (2007) Cellular antioxidant activity (CAA) assay for assessing antioxidants, foods, and dietary supplements. J Agric Food Chem 55, 8896-8907.

41. Shalaby SM, Zakora M \& Otte J (2006) Performance of two commonly used angiotensin-converting enzyme inhibition assays using FA-PGG and HHL as substrates. I Dairy Res 73, 178-186

42. Ranilla LGl, Genovese MI \& Lajolo FM (2009) Effect of different cooking conditions on phenolic compounds and antioxidant capacity of some selected Brazilian bean (Phaseolus vulgaris L.) cultivars. J Agric Food Chem 57, 5734-5742.

43. Hagerman AE, Riedl KM, Jones GA, et al. (1998) High molecular weight plant polyphenolics (tannins) as biological antioxidants. I Agric Food Chem 46, 1887-1892.

44. Xu B \& Chang SKC (2009) Phytochemical profiles and health-promoting effects of cool-season food legumes as influenced by thermal processing. I Agric Food Chem 57, 10718-10731

45. Lapidot T, Walker MD \& Kanner J (2002) Antioxidant and prooxidant effects of phenolics on pancreatic $\beta$-cells in vitro. J Agric Food Chem 50, 7220-7225.

46. Chow J-M, Shen S-C, Huan SK, et al. (2005) Quercetin, but not rutin and quercitrin, prevention of $\mathrm{H}_{2} \mathrm{O}_{2}$-induced apoptosis via anti-oxidant activity and heme oxygenase 1 gene expression in macrophages. Biochem Pharmacol 69, 1839-1851.

47. Seeram NP, Adams LS, Hardy ML, et al. (2004) Total cranberry extract versus its phytochemical constituents: antiproliferative and synergistic effects against human tumor cell lines. J Agric Food Chem 52, 2512-2517.

48. Seeram NP, Adams LS, Zhang Y, et al. (2006) Blackberry, black raspberry, blueberry, cranberry, red raspberry, and strawberry extracts inhibit growth and stimulate apoptosis of human cancer cells in vitro. I Agric Food Chem $\mathbf{5 4}$ 9329-9339.

49. Fulda S \& Debatin K-M (2006) Extrinsic versus intrinsic apoptosis pathways in anticancer chemotherapy. Oncogene 25, 4798-4811.

50. Naczk M, Amarowicz R, Zadernowski R, et al. (2001) Protein precipitating capacity of condensed tannins of beach pea, canola hulls, evening primrose and faba bean. Food Chem 73, 467-471

51. Zadernowski R, Borowska J, Naczk M, et al. (2001) Effect of broad bean and pea phenolics on the activity of lipase and lipoxygenase. J Food Lipids 8, 263-270.

52. Zhang L, Li J, Hogan S, et al. (2010) Inhibitory effect of rasberries on starch digestive enzyme and their antioxidant properties and phenolic composition. Food Chem 119, 592-599.

53. Silva Pinto M, Kwon Y-I, Apostolidis E, et al. (2008) Functionality of bioactive compounds in Brazilian strawberry (Fragaria $\times$ ananassa Duch.) cultivars: evaluation of hyperglycemia and hypertension potential using in vitro models J Agric Food Chem 56, 4386-4392.

54. Mai TT, Thu NN, Tien PG, et al. (2006) Alpha-glucosidase inhibitory and antioxidant activities of vietnamese edible plants and their relationships with polyphenol contents. J Nutr Sci Vitaminol 53, 267-276.

55. Helsper JPFG, Kolodziej H, Hoogendijk JM, et al. (1993) Characterization and trypsin inhibitor activity of proanthocyanidins from Vicia faba. Phytochem 34, 1255-1260. 
56. Lattanzio V, Bianco VV, Miccolis V, et al. (1986) Mono- and oligosaccharides in fifteen Vicia faba L. cultivars. Food Chem 22, 17-25.

57. Brown EG \& Roberts FM (1972) Formation of vicine and convicine by Vicia faba. Phytochem 11, 3203-3206.

58. Dundas DGA, Herderson HM \& Eskin NAM (1978) Lipase from Vicia faba minor. Food Chem 3, 171-178.

59. Amarowicz Y, Yoshiki Y, Pegg RB, et al. (1997) Presence of two saponins in faba bean (Vicia faba L.) seeds. Nahrung 41, 352-354.
60. Sharma A \& Sehgal S (1992) Effect of processing and cooking on the antinutritional factors of faba bean (Vicia faba). Food Chem 43, 383-385.

61. Deprez S, Mila I, Huneau J-F, et al. (2001) Transport of proanthocyanidin dimer, trimer, and polymer across monolayers of human intestinal epithelial Caco-2 cells. Antioxid Redox Signal 3, 957-967.

62. Monach C, Williamson G, Morand C, et al. (2005) Bioavailability and bioefficacy of polyphenols in humans. I. Review of 97 bioavailability studies. Am J Clin Nutr 81, 230-242. 